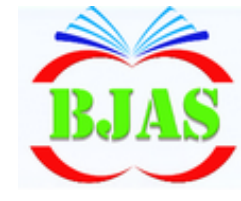

ISSN $1814-5868$
Available online at http://bjas.bajas.edu.iq

https://doi.org/10.37077/25200860.2021.34.1.08

College of Agriculture, University of Basrah

Basrah J. Agric. Sci. 34(1), 83-92, 2021

\section{Basrah Journal of Agricultural Sciences}

E-ISSN: 2520-0860

\title{
In Vitro Antioxidant Properties of Gum Extract From The Carob (Ceratonia silique L.) Plant
}

\author{
Marwah T. G. Al-Ameri* \& Amera K. Nasser \\ Department of Animal Production, College of Agriculture, University of Basrah, Iraq \\ *Corresponding author email: marwa.thamer90@gmail.com
}

Received 18 June 2020; Accepted 9 September 2020; Available online 13 February 2021

\begin{abstract}
The experiment was conducted in the laboratories of the College of Agriculture, University of Basra, for the period from 22/9/2019 to 25/ 11/2019. The current study aims to extract gum from the carob fruits, to determine the active substances and the possibility of using them as antioxidants. The results showed that the gum of the fruits of the carob plant contains all the active compounds under study, which included Alkaloids, Phenols, Flavonoids, Glycosides, Steroids, Tannins, Resins, Saponins and Coumarins. The results also showed that the gum of the fruits of the carob plant showed antioxidant activity of about $84.55 \%$ when used at a concentration of $0.2 \%$, while the average antioxidant efficacy of the industrial compound Butylated Hydroxy Toluene (BHT) and Ascorbic acid was about $93.43 \%, 91.12 \%$ at the same concentration. The Reductive power were about $73.20 \%$ and $83.30 \%$ with a concentration of $0.1 \%$ and $0.2 \%$ respectively, which was comparable to the effect of industrial antioxidants (BHT) and ascorbic acid with a concentration of $0.2 \%$, which was $91.40 \%$ and $90.70 \%$, respectively. In addition, the gum of the fruits of the carob plant has the potential to sweep hydrogen peroxide with a capacity similar to ascorbic acid and without significant difference $(\mathrm{p} \leq 0.05)$, reaching $41 \%$ and 50 $\%$ for concentrations $0.1 \%$ and $0.2 \%$, respectively, while ascorbic acid reached $45 \%$ with the presence of moral differences with the industrial antioxidant (BHT) in its susceptibility to the sweep of hydrogen peroxide at $73 \%$. The results also showed that the gum of the fruits of the carob plant is able to bind to the Ferrous ion and this portability increased with the increased concentration of gum to reach its highest average of $43.19 \%$ at the concentration of $0.2 \%$ while the average Ferrous ion for antioxidant (EDTA 2Na) was $55.48 \%$.
\end{abstract}

Keywords: Antioxidants, Carob fruits, Gum carob.

\section{Introduction}

Carob was a well-known Shrub for its nutritional and health-promoting edible pods due to its high phenolic contents (Chait et al., 2020). The carob tree (Ceratonia siliqua L.) mainly grows in mild and dry places with unproductive soils in Mediterranean countries including Greece and Turkey (Bernardo-Gil et $a l ., 2011)$. It has a variety of Practices the food manufacturing, such as gum, syrup, powder, biofertilizer, ethanol, mannitol, lactic acid, and citric acid (Oziyci et al., 2014). Gum was 
characterized by different physical characteristics, which was a multi-use substance it was an excellent reinforcement material and stabilizers for emulsions, and the absence of toxicity encourages it's used in the medical, pharmaceutical and food industries (Karababa \& Coşkuner., 2013). Many commercial companies used industrial antioxidants frequently in food conservation and the most commonly used antioxidants were Butylated Hydroxy Toluene (BHT) and Butylated Hydroxy Anisole (BHA), Recently there has been widespread fears about the safety of the use of industrial antioxidants due to their health status to the consumer, so the FDA has expressed concerns about the trend of artificial antioxidants in foods (Manhiani et al., 2013). Consequently, current work aimed to use the gum from $C$. siliqua and determined it's active substances, antioxidant potential and activity to capture free radicals.

\section{Materials \& Methods}

The experiment was conducted in the laboratories of the College of Agriculture, University of Basra, for the period from 22/9/2019 to $25 / 11 / 2019$.

\section{Collect and prepare samples}

The fruits of the carob plant were collect from Al-Ashar market, after which the fruits were cleaned, dried and milled in the electric mill smoothly and then placed in bags of polyethylene and stored in the refrigerator at a temperature of $4 \mathrm{C}^{\circ}$ until the tests are conduct.

\section{Extracting gum from the fruits of carob:}

\section{Oil Removing:}

The oil was extract from the fruits of the carob plant by following the cold extraction method using hexane (1: $5 \mathrm{w} / \mathrm{v})$ for six hours. The hexane was replenishes every hour by filtration (Marambe et al., 2008).

\section{Chemically gum extracting:}

The carob gum was extracted according to the optimal conditions mentioned by Al-Aubadi \& Al-Ani (2017) by mixing the carob plant with distilled water at a ratio of 1: $65(\mathrm{~W} / \mathrm{V})$ for 30 minutes with a pH 8 at $60 \mathrm{C}^{\circ}$. The gum deposition and purification process was carried out by adding ethanol $96 \%$ 1:2 filtrate: ethanol $(\mathrm{V} / \mathrm{V})$, the mixture was left overnight at $5 \mathrm{C}^{\circ}$ and filtered with a cotton sieve to separate the glue, a small percentage of distilled water was added and mixed it by using a magnetic motor, dry at $40 \mathrm{C}^{\circ}$ for 24 hours, Then, the gum was dried, then it's ground with a laboratory mill and the powder was stored in airtight ampoules.

\section{Calculating the yield of gum (Y):}

The percentage of the sum of the gum extracted according to Razavi et al. (2009), was calculated from the following equation:

$$
\begin{gathered}
\text { yield }=\frac{\text { Weight of extracted gum }(\mathrm{g})}{\text { weight of fruit carob }(\mathrm{g})} \times 100 \\
\text { yield }=\frac{140}{250} \times 100 \rightarrow \text { yield }=56(\mathrm{~g})
\end{gathered}
$$

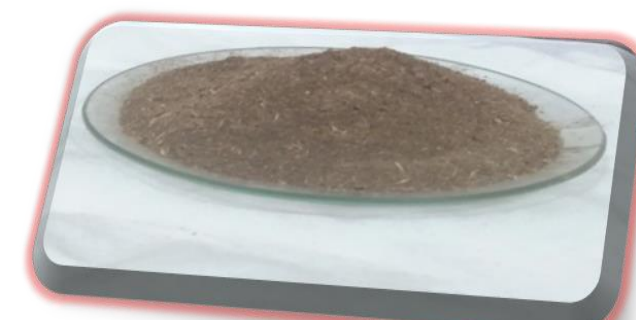

Fig.1 Gum of the fruits of the carob plant 


\section{Al-Ameri \& Nasser / Basrah J. Agric. Sci., 34(1): 83-92, 2021}

\section{Chemical detection of active substances:}

\section{Glycosides test}

The method used by Malayaman et al. (2019), mixing equal parts of carob plant with Benedict's reagent, red precipitation appears, indicating the presence of glycosides. The result of the confirmation depends on the reaction between the reagent and the sample, therefore, an equal amount of it's taken with the carob plant and the reaction was left in a boiling water bath for 10 minutes. The appearance of the red precipitate indicates positive detection of sugars.

\section{Alkaloids test}

Alkaloids were quantified according to AlDaihan et al. (2013), in which $100 \mathrm{mg}$ of the carob plant was soaked in $5 \mathrm{ml}$ of methanol, the mixture was filtered, $2 \mathrm{ml}$ of the nomination was taken and mixed with $5 \mathrm{ml}$ of hydrochloric acid at a concentration of $1 \%$, a few drops of Mayer's reagent and Draknov's reagent were added. The appearance of a reddish-orange precipitate indicates the presence of alkaloids.

\section{Saponins test}

The Saponins were detect in the manner mentioned by Sabreena (2019) by shaking the water extract to the gum of the carob in a test tube, if the detection was positive, the back of a thick foam stays for a long time.

\section{Coumarins test}

The Coumarins were detect in the manner mentioned before Malik et al. (1985). by taking $5 \mathrm{ml}$ of the gum extract of the fruits of the carob plant and put it in a test tube covered with filter paper moisturizing by sodium hydroxide (2n), put the tube in a boiled bath and the filtration sheet was presented to ultraviolet light using the UV-Scan device, a greenish yellow colour indicates the presence of the coumarins.

\section{Phenolic compounds test}

Phenols were detected using the method used by Samejo et al. (2013), $0.5 \mathrm{gm}$ of the carob plant was mixed with $10 \mathrm{ml}$ of distilled water, added to the filtered mixture, a few drops of $\mathrm{FeCl}_{3}$ to the juice at a concentration of $0.1 \%$. The appearance of a dark blue colour indicates the presence of phenols.

\section{Tannins test}

Tannins were reveal rendering to the method mentioned in Choudhary et al. (2013) As $0.5 \mathrm{~g}$ of carob plant was mixed in $20 \mathrm{ml}$ distilled water, the mixture was filtered and $\mathrm{FeCl}_{3}$ added $0.1 \%$ concentration. The appearance of a dark blue colour to indicate the presence of tannins

\section{Resins test}

The method used by Ehrnford et al. (1980) to detect resins:

Add $10 \mathrm{ml}$ of ethyl alcohol with a concentration of $95 \%$ to $1 \mathrm{~g}$ dry weight of carob plant, leave in boiling water bath for two minutes and leach sweetened, add to the filter $20 \mathrm{ml}$ distilled water acidified with drops of $\mathrm{HCl}$ acid concentration $4 \%$. The arrival of turbidity in the solution designates the presence of mastics.

\section{Flavonoids test}

Flavonoids were detect according to Samejo et al. (2013), mixing $0.5 \mathrm{~g}$ of carob with $10 \mathrm{ml}$ of ethanol, the filtrate was added to the filtrate some $\mathrm{Mg}$ and drops of concentrated $\mathrm{HCl}$ acid, the appearance of a red color indicating the presence of flavonoids. 


\section{Al-Ameri \& Nasser / Basrah J. Agric. Sci., 34(1): 83-92, 2021}

\section{Measuring antioxidant effectiveness}

Estimated according to the method mentioned in Al-Moussawi \& Al-Halfi (2012). The antioxidant activity was determined using the linoleic acid system, the reaction mixture consists of $4.1 \mathrm{ml}$ of linoleic acid at a concentration of $2.5 \%$ in ethanol, $4 \mathrm{ml}$ of alcohol extract, $8 \mathrm{ml}$ of 0.05 molar phosphate buffer solution 7 and $3.9 \mathrm{ml}$ distilled water, $1 \mathrm{ml}$ of 80 Tween at a concentration of $0.05 \%$ ethanol, the mixture was incubated at $40 \mathrm{C}^{\circ}$ for 24 hours. The degree of oxidation was determined by thiocyanate method, mix $0.1 \mathrm{ml}$ of the mixture, added $9.7 \mathrm{ml}$ of $75 \%$ ethanol and $0.1 \mathrm{ml}$ of ammonium thiocyanate at a concentration of $30 \%$, three minutes later, 0.1 $\mathrm{ml}$ ferrous chloride of 0.02 molar concentration prepared in $3.5 \%$ hydrochloric acid was added. The absorbance was measure at a wavelength of $500 \mathrm{~nm}$, Butylated Hydroxy Toluene (BHT) and ascorbic acid were used for comparison, and the control sample was prepared in the same way above except for mixing $4 \mathrm{ml}$ ethanol instead of plant extract. The percentage inhibition of linoleic fatty acid peroxides was calculated according to the following formula:

\% Antioxidant Effectiveness

$$
=\frac{\text { Sample absorbance reading }}{\text { The absorbance reading of the control }} \times 100
$$

\section{Measurement of Reducing Power}

The method mentioned in Al-Moussawi \& AlHalfi (2012) was followed which included mixing $2.5 \mathrm{ml}$ of alcoholic extract of carob gum with 2.5 phosphate buffer solution $200 \mathrm{mM}$ and $\mathrm{pH} 6.6$ and $2.5 \mathrm{ml}$ of potassium ferricyanide solution (1\%), bosom. The mixture at a temperature of $50 \mathrm{C}^{\circ}$ for 20 minutes after that the reaction was terminated by adding $2.5 \mathrm{ml}$ of
Trichloroacetic acid (10 \%). The central centrifugation of the mixture was perform at a speed of $2000 \mathrm{rpm}$ for 10 minutes. Separate the top layer of solution and add $5 \mathrm{ml}$ distilled water and $1 \mathrm{ml}$ ferric chloride $(0.1 \%)$. The absorption measurement was at a wavelength of $700 \mathrm{~nm}$. The control sample was prepared by adding all the previous materials except adding $2.5 \mathrm{ml}$ ethanol instead of the alcohol extract of the carob seeds. The following formula was apply to calculate the amount of the reducing strength of the extract:

$$
\begin{aligned}
& \% \text { Reducing Power } \\
& =100 \\
& -\frac{\text { Sample absorbance reading }}{\text { The absorbance reading of the control }} \times 100
\end{aligned}
$$

\section{Scavenging of Hydrogen Peroxide:}

Determined according to Türkoğlu et al. (2010) by taking $1-5 \mathrm{mg} \cdot \mathrm{ml}^{-1}$ of gum and $0.6 \mathrm{ml}$ of 0.002 molar $\mathrm{H}_{2} \mathrm{O}_{2}$ prepared in $0.1 \mathrm{mP}$ phosphate buffer at $\mathrm{pH} 7.4$, left for 10 minutes at laboratory temperature, measured Absorbance along $230 \mathrm{~nm}$, the equation was used below:

\% Capabilty of capture

$=\frac{\text { absorbance of the control sample }- \text { Sample reading }}{\text { absorbance of the control }}$

\section{Chelating ability of ferrous ion}

The method described in by Gülçın et al. (2003), mixed $0.4 \mathrm{ml}$ of alcoholic extract with $0.4 \mathrm{ml}$ of ferric chloride $2 \mathrm{ml}$ molar with $0.4 \mathrm{ml}$ 8-Hydroxyquinoline at a concentration of 5 molar (ethanol prepared), incubate the mixture for 10 minutes at room temperature in a dark place. The absorbance was measured along a $562 \mathrm{~nm}$ wavelength, the results were compared 
with (EDTA 2Na); the control sample was prepared in the same way except for the sample, the ability of the plant extract to chelate ferrous ion was calculated according to the following formula:

$\%$ Chelating ability of Ferrous ion

$=\frac{\text { Sample absorbance reading }}{\text { the absorbance reading of the control sample }} \times 100$

\section{Statistical analysis}

Data were statistically analysed using the SPSS statistical program (SPSS, 2006), and the data were compared using a Revised least significant difference (RLSD) at $\mathrm{p} \leq 0.05$ probability level. Using three replicates for each treatment.

\section{Results \& Discussions}

\section{Active compounds in the gum of the fruits of the carob plant:}

Chemical detection of active compounds in the gum of the fruits of the carob plant. Containing the alcohol extract on most of the active compounds under study, which included alkaloid, phenolic, flavonoid, glycoside, tannin, resins, saponins and coumarins, all of which gave positive results when inferred through the interactions shown in the table (1). These results came with what he arrived at Papagiannopoulos et al. (2004). Where he indicated that the fruits of the carob plant contain glycoside, tannin phenolic and flavonoid. The results also agreed with Ydjedd et al. (2017) and Correia et al. (2018); where they indicated that the fruits of the carob plant contain tannin phenolic and flavonoid.
Table (1): Detection results of active compounds in carob gum.

\begin{tabular}{lcc}
\hline $\begin{array}{c}\text { Active } \\
\text { compounds }\end{array}$ & Reagent uses & $\begin{array}{c}\text { Regent } \\
\text { results }\end{array}$ \\
\hline Glycoside & Benedict reagent & + \\
\hline Alkaloid & Mayer's Reagent & + \\
\hline Saponins & appearance of foam & + \\
\hline Coumarins & UV-Scan & + \\
\hline Resins & HCl acid & + \\
\hline Flavonoid & $\begin{array}{c}\text { Alkaline potassium } \\
\text { hydroxide }\end{array}$ & + \\
\hline Phenolic & Ferric chloride & + \\
\hline Tannin & Lead Acetate & + \\
\hline
\end{tabular}

\section{Measurement of antioxidant activity}

It's clear from the table (2) that the alcohol extract of carob plants showed significantly approach antioxidant effectiveness compared to industrial antioxidant BHT, The effectiveness of carob gum fruit was about $47.12 \%$ at a concentration of $0.1 \%$ and $84.55 \%$ at a concentration of $0.2 \%$, whereas the average anti-oxidant efficacy of BHT was about 93.43 $\%$, and the average oxidative effectiveness of ascorbic acid was $91.12 \%$, at a concentration of 0.2 , respectively.

Table. (2): Antioxidant activity of alcoholic extract of carob gum (mean \pm standard error)

\begin{tabular}{cc}
\hline Treatments & $\begin{array}{c}\text { Antioxidant activity } \\
\%\end{array}$ \\
\hline BHT & $93.43 \pm 0.0631^{\mathrm{a}}$ \\
\hline Ascorbic acid & $91.12 \pm 0.0073^{\mathrm{a}}$ \\
\hline Gum 0.2 & $84.55 \pm 0.1404^{\mathrm{b}}$ \\
\hline Gum 0.1 & $47.12 \pm 0.2311^{\mathrm{c}}$ \\
\hline
\end{tabular}


Means in the same column with different letters show significant differences $(p \leq 0.05)$.

The reason for the high efficacy of the gum extract and the carob plant as an antioxidant is due to the effective compounds of the carob plant, which are either hydrogen-or electron donors or have the ability to capture free radicals (Makris \& Kefalas, 2004).

\section{Measurement of Reducing Power}

Table (3) shows the reductive power of alcohol extract to glue of the fruits of the carob plant compared to ascorbic acid and industrial antioxidant (BHT), where the results showed that extract of gum of carob fruits possesses a reducing strength that increases to increase the concentration, as it averaged $73.20 \%$ at a concentration of $0.1 \%$ and $83.30 \%$ at a concentration of $0.2 \%$, It is an approach to industrial antioxidant and ascorbic acid at a concentration of 0.2 as it reached $91.40 \%$ and $90.70 \%$, respectively.

Table (3): Reducing power of alcohol extract for carob gum (Mean \pm standard error).

\begin{tabular}{cc}
\hline Treatments & Reducing power \% \\
\hline BHT & $91.40 \pm 0.1400^{\mathrm{a}}$ \\
\hline Ascorbic acid & $90.70 \pm 0.2333^{\mathrm{a}}$ \\
\hline Gum 0.2 & $83.30 \pm 0.1644^{\mathrm{b}}$ \\
\hline Gum 0.1 & $73.20 \pm 0.0221^{\mathrm{c}}$ \\
\hline
\end{tabular}

Means in the same column with different letters show significant differences $(p \leq 0.05)$.

As the intensity of the apparent colour indicates the reductive strength of the extract of gum fruits of the vegetable plant to give or release hydrogen ions or increase the hydroxyl root and thus increase the reducing strength, which was a significant indicator that reflects the antioxidant effectiveness (Al-Birawee \& Nasser, 2019).

\section{Measurement of scavenging hydrogen peroxide}

Table (4) shows that carob gum has the ability to sweep the hydrogen peroxide with the ability to resemble ascorbic acid and non-significant differences at $\mathrm{p} \leq 0.05$. As the averages of the alcoholic extract for carob plant fruits $41 \%$ and $50 \%$ for concentrations of $0.1 \%$ and $0.2 \%$, respectively. In addition to the significant differences between the alcoholic extract of the carrot gum and the industrial antioxidant (BHT) in its susceptibility to sweep the hydrogen peroxide, this process was very important to protect cellular systems, as hydrogen peroxide was a highly important compound because of its ability to penetrate cell membranes inside cells. Moreover, it's a toxic substance for cells because it raises the root of hydroxyl which has toxic effects.

Table. (4): Scavenging hydrogen peroxide of alcohol extract for carob gum. (Mean \pm standard error).

\begin{tabular}{cc}
\hline Treatments & $\begin{array}{c}\text { Scavenging hydrogen } \\
\text { peroxide \% }\end{array}$ \\
\hline BHT & $73.00 \pm 0.2140^{\mathrm{a}}$ \\
\hline Ascorbic acid & $45.00 \pm 0.1006^{\mathrm{b}}$ \\
\hline Gum 0.2 & $50.00 \pm 0.1222^{\mathrm{b}}$ \\
\hline Gum 0.1 & $41.00 \pm 0.2115^{\mathrm{b}}$ \\
\hline
\end{tabular}




\section{Al-Ameri \& Nasser / Basrah J. Agric. Sci., 34(1): 83-92, 2021}

Means in the same column with different letters show significant differences $(p \leq 0.05)$.

In addition, it could inhibited number of enzymes are oxidized by the primary tiol groups (SH-), which have a biological advantage for cells, to control the amount of hydrogen peroxide inside the cell. (Sikha, 2016).

\section{Measurement ferrous ion chelating}

Table (5) shows the ability carob gum to binding ferrous ion compared to the antioxidant. EDTA 2Na (Ethylene diamine tetraacetic acid).

Table (5): Ferrous ion chelating of alcohol extract for carob gum. (Mean \pm standard error).

Treatments Ferrous ion chelating \%

EDTA 2Na $\quad 55.48 \pm 5.0076^{\mathrm{a}}$

Gum $0.2 \quad 43.19 \pm 3.6541^{\mathrm{a}}$

Gum $0.1 \quad 32.91 \pm 4.0034^{\mathrm{a}}$

Means in the same letters show non-significant differences $(\mathrm{p} \leq 0.05)$.

The results showed in the table a highly significant susceptibility to gum of carob fruits to bind ferrous ion compared to the anti-oxidant (EDTA 2Na) and this ability amplified with increasing the concentration of the extract until it reached its highest average of $43.19 \%$ at a concentration of $0.2 \%$, while the average ferrous ion of the antioxidant reached $55.48 \%$ when comparing with the anti-oxidant (EDTA $2 \mathrm{Na}$ ), it was observed that the ability to bind ferrous ion by carob gum was almost as closed to that shown by the antioxidant, and the ability of the alcoholic extract for gum the carob to bind ferrous ion was due to the presence of a large number of active compounds which have a high ability to bind iron (Nagulendran et al., 2007).

\section{Conclusions}

The results showed that gum of carob fruits was rich in bioactive compounds, in addition, carob gum has antioxidant activity.

\section{Acknowledgements}

We offer sincere thanks and appreciation to members of the Department of Animal Production, especially Dr. Aliaa J. Shabeeb and Dr. Ghaida A. Makki to help us with laboratory work.

Conflict of interest: The authors declare that they have no conflict of interest.

ORCID: M.T.G. Al-Ameri https://orcid.org/00000002-1678-7907

ORCID: A.K. Nasser https://orcid.org/0000-00021716-2482

\section{References}

Al-Aubadi, I. M. K., \& Al-Ani, M. T. H. (2017) Determination of the physicochemical and organoleptic properties of Iraqi basil seeds gum (Ocimum basilicum) and detection of phytochemicals. Journal of the Biotechnology Research Center, 11, $10-16$.

https://www.iasj.net/iasj?func=fulltext\&aId=125802

Al-Birawee, A. R., \& Nasser, A. K. (2019). Gel extraction from caper fruits (Capparies spinosa L.) and assess its effectiveness as antioxidants. Basrah Journal Agricultural Sciences, 32, 74-84. https://doi.org/10.37077/25200860.2019.198

Al-Daihan, S., Al-Faham, M., Al-shawi, N., Almayman, R., Brnawi, A., \& Shafi Bhat, R. (2013). Antibacterial activity and phytochemical screening of some 


\section{Al-Ameri \& Nasser / Basrah J. Agric. Sci., 34(1): 83-92, 2021}

medicinal plants commonly used in Saudi Arabia against selected pathogenic microorganisms. Journal of King Saud University-Science, 25, 115-120. https://doi.org/10.1016/j.jksus.2012.11.003

Al-Moussawi, A. H. J., \& Al-Halfi, S. A. H. (2012). Isolation identification and determination the antioxidant activity of phenolic compound to some plants extracts. J. University of Karbala. $2^{\text {nd }}$ Sci. Conference Faculty Agriculture: 1218-1228. (In Arabic). https://www.iasj.net/iasj?func=fulltext\&aId=92740

Bernardo-Gil, M. G., Roque, R. Roseiro, L. B., Duarte, L. C., Gírio, F., \& Esteves, P. (2011). Supercritical extraction of carob kibbles (Ceratonia siliqua L.). J. Supercritical Fluids, 59, 36-42. https://www.sciencedirect.com/science/article/pii/S08 96844611003159

Chait, Y.A., Gunenc, A., Bendali, F. \& Hosseinian, F. (2020). Simulated gastrointestinal digestion and in vitro colonic fermentation of carob polyphenols: Bioaccessibility and bioactivity. LWT -Food Science Technology, $\quad 117, \quad 108623$. https://doi.org/10.1016/j.lwt.2019.108623

Choudhary, K., Singh, M., Meghwal, S. K., Mathuriya, B. L., \& Nagar, J. (2013). Study of phytochemical constituents and antimicrobial activity of common plants of hadoti region of Rajasthan, India. International Journal of Recent Biotechnology, 1216.

http://www.ijrbp.net/form/2013\%20Volume\%201,\%2 0issue\%201/IJRB-2013-1-1-12-16.pdf

Correia, P. J., Saavedra, T., Gama, F., da Graça Miguel, M., de Varennes, A., \& Pestana, M. (2018). Biologically active compounds available in Ceratonia siliqua L. grown in contrasting soils under Mediterranean climate. Scientia Horticulturae, 235, 228-234.

https://doi.org/10.1016/j.scienta.2018.03.010

Ehrnford, L., Derand, T., Larsson, L. A., \& Svensson, A. (1980). An abrasion test for composite resins. Journal of Dental Research, 59, 716-720. https://doi.org/10.1177\%2F00220345800590040801

Gülçın, İ., Oktay, M., Kıreçcı, E., \& Küfrevıoğlu, Ö. İ. (2003). Screening of antioxidant and antimicrobial activities of anise (Pimpinella anisum L.) seed extracts. Food Chemistry, 83, 371-382. https://www.sciencedirect.com/science/article/abs/pii/ S0308814603000980

Karababa, E., \& Coşkuner, Y. (2013). Physical properties of carob bean (Ceratonia siliqua L.): An industrial gum yielding crop. Industrial Crops Products, 42, 440-446.

https://www.sciencedirect.com/science/article/abs/pii/ S0926669012002713

Makris, D. P., \& Kefalas, P. (2004). Carob pods (Ceratonia siliqua L.) as a source of polyphenolic antioxidants. Food Technology and Biotechnology, 42 , 105-108. file:///C:/Users/Ali\%20Ahmed/Downloads/42_105\% 20(2).pdf

Malayaman, V., Sheik Mohamed, S., Senthilkumar, R. P., \& Ghouse Basha, M. (2019). Analysis of phytochemical constituents in leaves of Bhumyamalaki (Phyllanthus debilis Klein \& Willd.) from Servaroy hills, Tamil Nadu, India. Journal of Pharmacognosy and Phytochemistry, 8, 26782683.http://www.phytojournal.com/archives/?year $=2$ $019 \&$ vol $=8 \&$ issue $=1 \&$ ArticleId $=7182$

Malik, S., Cun-Heng, H., \& Clardy, J. (1985). Isolation and structure determination of nigellicine, a novel alkaloid from the seeds of Nigella sativa. Tetrahedron letters, 26(23), 2759-2762. https://www.sciencedirect.com/science/article/pii/S00 40403900949049

Manhiani, P. S., Northcutt, J. K., Han, I., Bridges, W. C., \& Dawson, P. L. (2013). Antioxidant activity of carnosine extracted from various poultry tissues. Poultry Science, 92, 444-453. https://www.sciencedirect.com/journal/poultryscience

Marambe, P. W. M. L. H. K., Shand, P. J., \& Wanasundara, J. P. D. (2008). An in-vitro investigation of selected biological activities of hydrolysed flaxseed (Linum usitatissimum L.) proteins. Journal of the American Oil Chemists' Society, $\quad 85$, 1155-1164. https://doi.org/10.1007/s11746-008-1293-z 


\section{Al-Ameri \& Nasser / Basrah J. Agric. Sci., 34(1): 83-92, 2021}

Nagulendran, K. R., Velavan, S., Mahesh, R., \& Begum, V. H. (2007). In vitro antioxidant activity and total polyphenolic content of Cyperus rotundus rhizomes. Journal of Chemistry, 4, 440-449. file:///C:/Users/Ali\%20Ahmed/Downloads/903496.pd f

Oziyci, H.R., Tetik, N., Turhan, I., Yatmaz, E., Ucgun, K., Akgul, H., \& Karhan, M. (2014). Mineral composition of pods and seeds of wild and grafted carob (Ceratonia silique L.). fruits. Scientia Horticulturae, 167, 149-152. https://doi.org/10.1016/j.scienta.2014.01.005

Papagiannopoulos, M., Wollseifen, H. R., Mellenthin, A., Haber, B., \& Galensa, R. (2004). Identification and quantification of polyphenols in carob fruits (Ceratonia siliqua L.) and derived products by HPLC-UV-ESI/MS n. Journal of Agricultural and Food Chemistry, 52, 3784-3791. https://doi.org/10.1021/jf030660y

Razavi, S. M., Mortazavi, S.A., Matia Merino, L., Hosseini Parvar, S. H., Motamedzadegan, A., \& Khanipour, E. (2009). Optimisation study of gum extraction from Basil seeds (Ocimum basilicum L.). International Journal of Food Science and Technology, 44, 1755-1762. https://ifst.onlinelibrary.wiley.com/doi/abs/10.1111/j. 1365-2621.2009.01993.x

Sabreena, H. (2019). Study the biological efficacy of some medicinal plants Minth (sic) and Basil (sic). M. Sc. Thesis. College of Technology, University of Shaheed Hama Lakhdar Al-Wadi, Algeria, 67pp. (In
Arabic).http://193.194.92.111/bitstream/123456789/3 486/1/660-101.pdf

Samejo, M. Q., Sumbul, A., Shah, S., Memon, S. B., \& Chundrigar, S. (2013). Phytochemical screening of Tamarix dioica Roxb. ex Roch. Journal of Pharmacy Research, 7, 181-183. https://doi.org/10.1016/j.jopr.2013.02.017

Sikha, B. (2016). An assessment of antioxidant and antiproliferative activities of super grain quinoa. Journal of Food Processing and Technology, 7, http://www.omicsonline.org/open-access/anassessment-of-antioxidant-and-antiproliferativeactivities-of-supergrain-quinoa-2157-71101000549.pdf

SPSS (2006). Statistical Packages of Social Sciences. Version 15 for windows. SPSS. Inc..

Türkoğlu, S., Çelik, S., Türkoğlu, I., Çakılcıŏlu, U., \& Bahsi, M. (2010). Determination of the antioxidant properties of ethanol and water extracts from different parts of (Teucrium parviflorum) Schreber. African Journal of Biotechnology, 9, 6797-6805. https://doi.org/10.5897/AJB10.814

Ydjedd, S., Bouriche, S., López-Nicolás, R., SánchezMoya, T., Frontela-Saseta, C., Ros-Berruezo, G., \& Kati, D. E. (2017). Effect of in vitro gastrointestinal digestion on encapsulated and nonencapsulated phenolic compounds of carob (Ceratonia siliqua L.) pulp extracts and their antioxidant capacity. Journal of Agricultural and Food Chemistry, 65, 827-835. https://doi.org/10.1021/acs.jafc.6b051 


\section{Al-Ameri \& Nasser / Basrah J. Agric. Sci., 34(1): 83-92, 2021}

خصائص مضادات الاكسدة لمستخلص صمغ نبات الخروب (Ceratonia silique L.) خارج جسم الكائن الحي مروة ثامر غياض العامري واميرة كاظم ناصر

$$
\text { قسم الإنتاج الحيو اني، كلية الزراعة، جامعة البصرة، العر اق. }
$$

المستخلص: أجريت التجربة في مختبرات كلية الزر اعة جامعة البصرة للفترة من 2019/9/22 إلى 2019/11/25. تهدف الدراسة الحالي إلى استخلاص الصمغ من ثمار الخروب وتحديد المواد الفعالة وإمكانية استخدامه كمضادات اكسدة. أظهرت النتائج أن صمغ ثمار نبات الخرنوب يحتوي على جميع المركبات الفعالة قيد الدراسة، والتي شملت القلويات، الفينولات، الفلافونيدات، الكلايكوسيدات، التانينات، الر اتتجات، الصابونيات و الكومارينات. كما أظهرت النتائج أن صمغ ثمار نبات الخرنوب امتلك نشاطًا مضادًا للأكسدة بنسبة 84.55٪ عند استخدامها بتركيز 0.2٪، في حين كان منوسط الفعالية المضادة للأكسدة وحامض الاسكوربيك حوالي 93.43٪، 91.12\% بنفس التركيز . والقوة الاختز الية بلغت حو الي 73.20\% بتركيز 0.1\% وحو الي 83.30\% بتركيز 0.2\%، و هي نتائج مقاربة لتأثير مضادات الأكسدة الصناعية (BHT) وحامض الاسكوربيك بتركيز 0.2\% و التي بلغت 91.40\% و 90.70 \% \% على التوالي. وبالإضافة إلى ذللك، فإن صمغ ثمار نبات الخرنوب لديه القدرة على اكتساح بيروكسيد الهيدروجين بقدرة مماتلة لحامض الاسكوربيك ودون اختلاف معنوي لتصل إلى 41٪ و 50٪ للتر اكيز 0.1\% و 0.2 \% على التوالي، في حين أن حامض الاسكوربيك وصل إلى 45٪ ، مع وجود اختلافات معنوية مع مضادات الأكسدة الصناعي (BHT) في قابليتها لاكتساح بيروكسيد الهيدروجين حيث بلغ 73 \%.كما أظهرت النتائج أن صمغ ثمار نبات الخرنوب قادرة على ربط أيون الحديدوز وتزداد قابلية الربط هذه مع زيادة تركيز الصمغ لتصل إلى أعلى منوسط لها 43.19\% عند نركيز 0.2\% في حين أن منوسط ايون الحديدوز لمضادات الأكسدة (EDTA 2Na) بلغ حوالي 